\title{
Scarlet Macaw (Ara macao, Psittaciformes: Psittacidae) Nest Characteristics in the Osa Peninsula Conservation Area (ACOSA), Costa Rica
}

\author{
John L. Guittar ${ }^{1,2}$, Fiona Dear ${ }^{3}$ \& Christopher Vaughan ${ }^{2,4,5}$ \\ 1. Grinnell College, Grinnell, IA 50112, USA; guittarj@gmail.com \\ 2. Associated Colleges of the Midwest, Apartado 10265, San Jose, Costa Rica \\ 3. University of East Anglia, Norwich, NR4 7TJ, UK; fiona_dear@hotmail.com \\ 4. University of Wisconsin/Madison, WI 53706, USA; cvaughan@wisc.edu \\ 5. International Institute in Wildlife Conservation and Management, Universidad Nacional, Costa Rica
}

Received 29-V-2008. Corrected 10-X-2008. Accepted 08-XI-2008.

\begin{abstract}
The Scarlet Macaw (Ara macao) is an endangered species. In Costa Rica, the Scarlet Macaw population of the Central Pacific Conservation Area (ACOPAC, $n=432$ individuals) has undergone considerable study and has been used effectively as a flagship species for regional conservation. Costa Rica's only other viable Scarlet Macaw population, located in the Osa Peninsula Conservation Area (ACOSA, $n=800-1200$ individuals), remains virtually unstudied. We studied ACOSA Scarlet Macaw nest cavities from February $19^{\text {th }}$ to March $22^{\text {nd }}$ 2006. Through informal interviews with park guards and residents, we found a total of 57 potential nests in 52 trees. Eleven nests were reported as frequently poached. Scarlet Macaws used 14 identified tree species, ten of which are unrecorded in Costa Rica. The most common nesting trees were Caryocar costaricense ( $\mathrm{n}=12,24 \%$ ), Schizolobium parahyba $(\mathrm{n}=9,18.0 \%)$, Ceiba pentandra $(\mathrm{n}=7,14.0 \%)$ and Ficus $s p .(\mathrm{n}=5,10.0 \%)$. We compare nesting characteristics to those recorded in ACOPAC. A combination of bottom-up and top-down strategies are necessary to ensure the Scarlet Macaw's long-term success, including environmental education in local schools, community stewardship of active nests, and the advertisement of stricter penalties for poaching. Rev. Biol. Trop. 57 (1-2): 387-393. Epub 2009 June 30.
\end{abstract}

Key words: Ara macao, Costa Rica, nest cavities, Osa Peninsula, Scarlet Macaw.

The Scarlet Macaw, an iconic Psittacine of the Neotropics, once ranged from Mexico to Bolivia (Marineros and Vaughan 1995). As with most macaws, the Scarlet Macaw's range is now fragmented and reduced due to habitat destruction and intense poaching for the pet trade (Snyder et al. 1992, Vaughan et al. 2003a). Because of these threats, the Convention on International Trade of Endangered Species (CITES) listed the Scarlet Macaw as an endangered species on Appendix 1 in 1985 (Marineros and Vaughan 1995).

In Costa Rica, two viable Scarlet Macaw populations remain. One population, located in the Central Pacific Conservation Area (ACOPAC, $\mathrm{n}=432$ individuals), has been studied for over 15 years (Marineros and Vaughan 1995, Vaughan et al. 2003a, Myers and Vaughan 2004, Vaughan et al. 2005). The other, suspected as genetically isolated (Nader et al. 1999), is found in the Osa Peninsula Conservation Area (ACOSA, $\mathrm{n}=800-1200$ individuals) and is virtually unstudied (Dear et al. 2005).

The effect of habitat destruction and poaching on Scarlet Macaw populations is worsened by naturally low rates of reproductive success. In one study of 52 acres of Peruvian floodplain forest, only $10-20 \%$ of Scarlet Macaw pairs bred and 33\% of nests failed (Munn 1992). A high rate of Neotropical tree turnover further compromises successful breeding. In ACOPAC, 
Vaughan et al. (2003a) found dead and living trees with Scarlet Macaw nests to fall at annual rates of $22 \%$ and $8 \%$, respectively. The low rate of Scarlet Macaw recruitment may slow population recovery in reduced populations (Bennett and Owens 1997).

Nesting behavior studies and local community awareness enabled Vaughan et al. (2003b) and Vaughan et al. (2005) to implement conservation strategies on ACOPAC Scarlet Macaws with some success. Demonstrably effective practices, such as stakeholder participation, poacher identification, and artificial and natural nest protection, must be considered for ACOSA Scarlet Macaws. The objective to this study was to a) locate, describe, and assess current threats to ACOSA Scarlet Macaw nesting cavities, b) compare these data to ACOPAC Scarlet Macaw nesting cavities, and c) discuss resultant conservation implications.

\section{MATERIALS AND METHODS}

Study site: ACOSA is located in southwestern Costa Rica $\left(08^{\circ} 42^{\prime} \mathrm{N}, 83^{\circ} 29^{\prime} \mathrm{W}\right)$ and consists of $410,400 \mathrm{~km}^{2}$ of mostly lowland humid forest (Quesada et al. 1997) (Fig. 1). The area receives between $2.5 \mathrm{~m}$ and $3.3 \mathrm{~m}$ of annual precipitation and has a mean annual temperature of $24-28^{\circ} \mathrm{C}$ (Herrera 1986). Seventeen protected wildland areas cover 145,425 hectares in ACOSA (García 1997). Most of the remaining land is in production of African palm oil, teak, and cattle pastures, or in land use as fallow ground, private forests or small villages.

We studied ACOSA Scarlet Macaws during the nesting season, from February 19-April 22 , 2006. To locate potential nesting cavities, we combined past interview data (Dear et al. 2005) with visits to landowners, farmers, park guards, and tour guides. We confirmed Scarlet Macaw activity for each cavity with: a) evidence of feathers or eggshells on the ground underneath the cavity, b) observation of Scarlet Macaws entering or exiting the cavity, or c) testaments from reliable local sources. We climbed two trees to confirm nesting activity. Large-scale locating of nesting cavities necessitates local assistance; much of the southwest

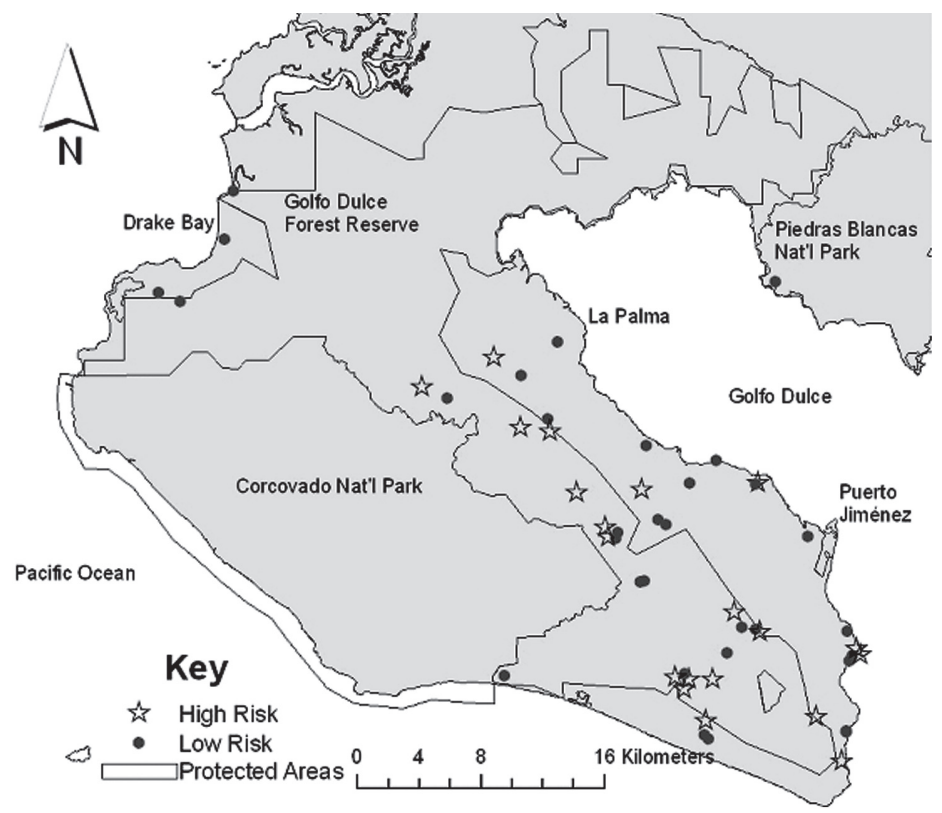

Fig. 1. Study area for Scarlet Macaw (Ara macao) nesting in the Osa Peninsula Conservation Area (ACOSA). All points represent potential Scarlet Macaw natural nesting sites. 
corner of ACOSA was unexplored because of a lack of human inhabitants within Corcovado National Park.

At each potential nesting cavity, we collected: a) tree species, identified by submitting samples to INBio (Instituto Nacional de Biodiversidad), or personal observation confirmed using Quesada (1997); b) latitude/longitude, determined by a Garmin 12 GPS; c) photographic voucher of tree and cavity; d) tree status, considered "dead" if all leaves were absent and wood appeared rotten, otherwise "alive;" e) cavity height, as distance from ground to cavity opening, estimated to the nearest meter by using a person of known height standing adjacent to the tree for reference; f) tree height, by same method as nest height; g) cavity orientation, recorded with a compass; h) cavity location on branch or trunk; and i) habitat, categorized by observation as pasture (few scattered trees), secondary forest (pioneering species recovering from disturbance), or primary forest (undisturbed private or protected reserves).

We determined potential and actual poaching by assessing cavity accessibility and interviewing park guards and/or local contacts near nesting areas. Climbing difficulty of each cavity was rated considering local techniques (ropes and spiked tree-climbing boots), cavity location, and apparent tree stability (1-easy, 2-medium, 3-difficult). Nests reported as poached were tagged as "high-risk" (Fig. 1).

\section{RESULTS}

In nine weeks, we found 57 potential nesting cavities in 52 trees $(5.9 \pm \mathrm{SD} 4.9 \mathrm{hrs} /$ person/ nest) (Table 1). Three trees held multiple nests: a Caryocar costaricense tree had four nests,

TABLE 1

Nesting tree and cavity data for the Scarlet Macaw (Ara macao) population in the Osa Peninsula Conservation Area (ACOSA)

\begin{tabular}{|c|c|c|c|c|c|c|}
\hline \multirow{2}{*}{ Tree Species } & \multirow{2}{*}{ Nest \# $(\%)^{1}$} & \multirow{2}{*}{$\begin{array}{l}\text { Tree Height }(\mathrm{m}) \\
(\text { Mean }) \pm \mathrm{SD}\end{array}$} & \multirow{2}{*}{$\begin{array}{l}\text { Nest Height }(\mathrm{m}) \\
(\text { Mean }) \pm \mathrm{SD}\end{array}$} & \multicolumn{3}{|c|}{ Nest Cavity Location } \\
\hline & & & & Living Trees & Branches & Trunks \\
\hline Caryocar costaricense & $12(24)$ & $28 \pm 6$ & $24 \pm 8$ & $4 / 12$ & 3 & 9 \\
\hline Schizolobium parahyba & $9(18)$ & $35 \pm 5$ & $20 \pm 5$ & $9 / 9$ & 4 & 5 \\
\hline Ceiba pentandra & $7(14)$ & $45 \pm 9$ & $28 \pm 7$ & $7 / 7$ & 3 & 4 \\
\hline Ficus sp. & $5(10)$ & $35 \pm 11$ & $22 \pm 8$ & $5 / 5$ & 2 & 3 \\
\hline Quiina sp. & $4(8)$ & $39 \pm 5$ & $19 \pm 5$ & $4 / 4$ & 2 & 2 \\
\hline Humiriastrum diguense & $2(4)$ & $30 \pm 4$ & $20 \pm 7$ & $1 / 2$ & 1 & 1 \\
\hline Hyeronima alchorneoides & $2(4)$ & $30 \pm 7$ & $20 \pm 1$ & $1 / 2$ & 1 & 1 \\
\hline Paramachaerium gruberi & $2(4)$ & $36 \pm 6$ & $20 \pm 7$ & $2 / 2$ & 0 & 2 \\
\hline Sterculia apetala & $2(4)$ & $45 \pm 7$ & $36 \pm 9$ & $2 / 2$ & 1 & 1 \\
\hline Brosimum alicastrum & $1(2)$ & 35 & 20 & $1 / 1$ & 0 & 1 \\
\hline Myroxylon balsamum & $1(2)$ & 55 & 30 & $1 / 1$ & 0 & 1 \\
\hline Ochroma pyramidale & $1(2)$ & 40 & 30 & $0 / 1$ & 0 & 1 \\
\hline Qualea paraensis & $1(2)$ & 35 & 28 & $1 / 1$ & 1 & 0 \\
\hline Vochysia sp. & $1(2)$ & 32 & 24 & $0 / 1$ & 0 & 1 \\
\hline Unknown $^{2}$ & $7(0)$ & $34 \pm 11$ & $20 \pm 7$ & $3 / 5$ & 0 & 5 \\
\hline Totals: & 57 & $37 \pm 9$ & $24 \pm 7$ & $41 / 55$ & 18 & 37 \\
\hline
\end{tabular}

1. Percentages are calculated as: (nests) / (total number of nests in identified trees (50)).

2. Height and cavity location data for two cavities were omitted due to missing data. 
a Ficus sp. had two nests, and a Quiina $s p$. also had two nests. Of the two nests climbed, one had no evidence of eggs or chicks, and the other had one chick that later successfully fledged. Our biased methods for locating nests invalidate nest density analysis.

Scarlet Macaws used a greater number of tree species for nesting in ACOSA than ACOPAC (14 vs. 11) (Vaughan et al. 2003a) (Table 1, Table 2), and only four species overlap. The local interviews (Dear et al. unpubl. data) reference nine additional potential nesting tree species, six of which are new: Aspidosperma myristicifolium, A. spruceanum, Brosimum alicastrum, Calophyllum brasiliense, Carapa guianensis, Couratari scottmorii, Ormosia spp, Terminalia oblonga. Cavities in identified trees $(\mathrm{n}=50)$ included $12(24 \%)$ Caryocar costaricense, 9 (18\%) Schizolobium parahyba, 7 (14\%) Ceiba pentandra, and 5 (10\%) Ficus sp. Seven (7) dead trees had no identifying characteristics (Table 1). Average cavity height (24 $\pm 7 \mathrm{~m} \mathrm{SD})$, ratio of living trees (41/55), and branch to trunk ratio $(18: 37)$ were similar to ACOPAC data (Table 2). ACOSA cavity height ranged from $13 \mathrm{~m}$ to $30 \mathrm{~m}$. We located more nesting cavities in ACOSA pastures (47\%) than Vaughan et al. (2003a) found in ACOPAC pastures (29\%) (Table 3), although this result is subject to bias.

ACOSA Scarlet Macaws can coexist with moderate human development. We found a nesting cavity in a Hyeronima alchorneoides located on the Puerto Jiménez (town pop: 4000) high school property, and a nest carved in the side of a secluded but inhabited wooden cabin. Further, we observed daily foraging on beach-almond trees (Terminalia catappa) in the Puerto Jimenez city park and other town sites. Locals reported eleven (19\%) of the 57 potential nesting cavities as recently poached and all were on private lands (Fig. 1). Of the 57 potential nesting cavities, 23 were $20 \mathrm{~m}$ high or less. Fourteen (14) were "easy" to climb, 28 were of "moderate" difficulty to climb, and 15 were "difficult" to climb. One poacher reportedly

TABLE 2

Nesting tree and cavity data for the Scarlet Macaw (Ara macao) population in the Central Pacific Conservation Area (ACOPAC) ${ }^{1}$

\begin{tabular}{|c|c|c|c|c|c|}
\hline \multirow{2}{*}{ Tree Species } & \multirow{2}{*}{ Nest \# (\%) } & \multirow{2}{*}{$\begin{array}{l}\text { Nest Height }(\mathrm{m}) \\
\quad(\text { Mean } \pm \text { SD) }\end{array}$} & \multicolumn{3}{|c|}{ Nest Cavity Location } \\
\hline & & & Alive trees & Branches & Trunks \\
\hline Schizolobium parahyba & $17(37)$ & $20 \pm 5$ & $15 / 17$ & 8 & 9 \\
\hline Ceiba pentandra & $10(22)$ & $27 \pm 9$ & $7 / 10$ & 3 & 7 \\
\hline Astronium graveolens & $3(7)$ & $24 \pm 6$ & $3 / 3$ & 0 & 3 \\
\hline Hura crepitans & $3(7)$ & $25 \pm 5$ & $3 / 3$ & 1 & 2 \\
\hline Rhizophora mangle & $3(7)$ & $8 \pm 0$ & $3 / 3$ & 1 & 2 \\
\hline Terminalia oblonga & $3(7)$ & $18 \pm 8$ & $3 / 3$ & 1 & 2 \\
\hline Brosimum utile & $2(4)$ & $28 \pm 4$ & $2 / 2$ & 0 & 2 \\
\hline Sterculia apetala & $2(4)$ & $27 \pm 19$ & $2 / 2$ & 1 & 1 \\
\hline Anacardium excelsum & $1(3)$ & 11 & $1 / 1$ & 1 & 0 \\
\hline Avicennia nitida & $1(3)$ & 28 & $1 / 1$ & 1 & 0 \\
\hline Myroxylon balsamum & $1(3)$ & 20 & $0 / 1$ & 0 & 1 \\
\hline Unknown species & 10 & $20 \pm 10$ & $2 / 10$ & 4 & 6 \\
\hline Totals & 56 & $21 \pm 8$ & $42 / 56$ & 21 & 35 \\
\hline
\end{tabular}

1. Adapted from Vaughan et al. (2003b) 
TABLE 3

Habitat types of potential nesting cavities for Scarlet Macaws in the Osa Peninsula Conservation Area (ACOSA) and the Central Pacific Conservation Area $(A C O P A C)^{1}$

\begin{tabular}{lcc}
\multicolumn{1}{c}{ Habitat } & ACOSA \# (\%) & ACOPAC \# (\%) \\
Pasture & $27(47)$ & $16(29)$ \\
Secondary Forest & $17(30)$ & $19(34)$ \\
Primary Forest & $14(24)$ & $17(30)$ \\
Mangrove Swamp & $0(0.0)$ & $4(7)$
\end{tabular}

1. Data for ACOPAC from Vaughan et al. (2003b)

takes 25 chicks/yr from the ACOSA area (Dear et al 2005), and another may annually raid at least five nests. During an informal interview, an ex-poacher referenced a buyer near the Panamanian border paying \$200/chick.

\section{DISCUSSION}

The high variability in cavity height, cavity location, tree height, and tree species suggests that ACOSA Scarlet Macaws do not select nest sites based on any one of these characteristics. This flexibility is large relative to many other Neotropical Parrots, such as the Lilac-Crowned parrot (Amazona finchi) (Renton and Salinas 1999), and Amazon parrots in northeastern Mexico (Christman and Dhondt 1997), which both show clear preference for specific nesting tree species and nest height. Indeed, our study contributes ten new potential nesting tree species recorded for Scarlet Macaws in Costa Rica. Six additional species referenced in interviews (Dear et al. 2005), and our survey's omission of Corcovado National Park, suggest more exist.

Availability of secure and popular ACOSA nesting trees might improve reproductive success of ACOPAC Scarlet Macaws, and vise versa. Prime examples are Caryocar costaricense and Ficus sp., two major ACOSA nesting trees not recorded in ACOPAC. C. costaricense is a long-living $35-50 \mathrm{~m}$ tree with a dry trunk which forms high, natural cavities $(\mathrm{n}=12$, mean cavity height $24.0 \pm 8.0$ ) (personal observation, Quesada et al. 1997). Ficus. sp. also has a high average nest height $(\mathrm{n}=5,22 \pm 8$ $\mathrm{m})$. Geographic ranges for both trees include ACOPAC (Quesada et al. 1997), and both are appropriate shade trees in pastures.

Ideal Scarlet Macaw nesting cavities are found in stable living trees, located as far from the ground as possible, and in close proximity to potential guardians. Low cavities are most susceptible to poaching and/or arboreal threats such as the Black Iguana (Ctenosaura similes), the common opossum, (Didelphis marsupialis), and monkey vandalism (Vaughan et al. 2003a). We recommend that cavities close to the ground and/or those suspected of being poached should be removed, closed, or closely guarded during the nesting season. Although artificial Scarlet Macaw nest boxes have had low success rates (Vaughan 2003a), they may provide future nesting alternatives, especially if concentrated near active nests so that several nests could be protected simultaneously. Plans detailed in Nycander (1995) or Vaughan et al. (2005) provide suggestions for future design.

The influence of habitat loss and poaching on Scarlet Macaw populations is exacerbated by a naturally small clutch size and a low chick survival rate (Wright et al. 2001). An understanding of Scarlet Macaw reproduction is crucial for its conservation, and can be used to inform environmental education projects, artificial nest construction, and grass-roots ecotourism. Our initial survey of potential ACOSA Scarlet Macaw nests should be followed by long-term cavity monitoring, especially fledgling counts and nest cavity reuse studies.

Conservation implications: The Scarlet Macaw has been used effectively as a flagship species to promote conservation and environmental education in ACOPAC (Vaughan et al. 2003b); ACOSA, where the Scarlet Macaw thrives, should do the same. One example could be an annual school course which encourages children to estimate Scarlet Macaw population size, or excursions to see artificial and natural Scarlet Macaw nests. The nest located on the 
Puerto Jiménez High School campus is an ideal location to begin such a program.

Present and future ACOSA cattle farms, especially those adjacent to forested areas, should be informed about Scarlet Macaw conservation efforts and encouraged to plant and/ or guard popular nesting trees and food sources in their pastures. These trees would benefit the Scarlet Macaw population and other wildlife species, provide natural shade for the farmer's cattle, and provide aesthetic value to their land. Later, farms with known Scarlet Macaw nests could potentially profit from the Scarlet Macaw as an ecotourism icon.

Lastly, poaching in ACOPAC should be further investigated and actively discouraged. While only 11 of 57 ACOSA cavities were reported as poached, the actual number is likely greater. Costa Rica's Ministry for the Environment (MINAE) should continue to dissuade known poachers and work towards identifying unknown poachers. MINAE should advertise stricter penalties, while reminding the public of the legal and environmental consequences of poaching, and suggesting ecofriendly alternatives.

\section{ACKNOWLEDGMENTS}

We are thankful to many community members including Adrian Morales Polanco, Eduvijes de Bahia Drake, and Lana Luna for lodging and assistance with finding nests. Andy Pruter provided tree climbing materials. Hayder Santamaria, Eliecer Arce, and MINAE offered transportation, logistical advice, and nest information. Local botanist Reinaldo Aguilar from INBio assisted in identifying nesting tree species. Lastly, we are thankful to Associated Colleges of the Midwest (ACM), The Parrot Society-UK and Amigos de la Osa for funding.

\section{REFERENCES}

Bennett, P. M., I. P. F. Owens. 1997. Variation in extinction risk among birds: chance or evolutionary predisposition? Proceedings of the Royal Society of London, Series B 264: 401-408.

Christman, B. J., A. A. Dhondt. 1997. Nest predation in Black-capped Chickadees: how safe are cavity nests? Auk. 114: 769-773.

Dear, F., C. Vaughan, A. Morales. 2005. Current status and conservation of the Scarlet Macaw (Ara macao) in the Osa Conservation Area (ACOSA), Costa Rica. International Institute for Wildlife Conservation and Management, Universidad Nacional, Costa Rica. Mimeographed.

García, R. 1997. Biología de la Conservación y Áreas Silvestres Protegidas: Situación Actual y Perspectivas en Costa Rica. Instituto Nacional de Biodiversidad Press, Santo Domingo, Costa Rica.

Herrera, W. 1986. Clima de Costa Rica. Editorial Univ. Estatal de Distancia, San José, Costa Rica.

Marineros, L., \& C. Vaughan. 1995. Scarlet Macaws of Carara, p. 445-467. In Abramson, J., B. Speer, \& J. Thomsen (eds.). The large macaws: Their care, breeding and conservation. Raintree Publications, Fort Bragg, California, USA.

Munn, C. 1992. Macaw biology and ecotourism or, "When a bird in the hand is worth two in the bush." p. 47-72. In Beissinger, S., \& N. Snyder (eds.). New World parrots in crisis: Solutions from conservation biology. Smithsonian Institution Press, Washington, D.C., USA.

Myers, M. \& C. Vaughan. 2004. Movement and behaviour of scarlet macaws (Ara macao) during the postfledgling dependence period: implications for in situ versus ex situ management. Biol. Conserv. 118: 411-420.

Nader, W., D. Werner, M. Wink. 1999. Genetic diversity of scarlet macaws Ara macao in reintroduction studies for threatened populations in Costa Rica. Biol. Cons. 87: 269-272.

Nycander, E., D. Blanco, K. Holle, A. del Campo, C. Munn, J. Moscoso, \& D. Ricalde. 1995. Nesting success and techniques for increasing reproduction 
in wild macaws in southwestern Peru, p. 423-444. In Abramson, J., B. Speer, \& J. Thomsen (eds.). The large macaws: Their care, breedg and conservation. Raintree Publications, Fort Bragg, California, USA.

Quesada, F. J., Q. Jiménez, N. Zamora, R. Aguilar, \& J. Gonzáles. 1997. Árboles de la Península de Osa. Instituto Nacional de Biodiversidad Press, Heredia, Costa Rica.

Renton, K., A. Salinas. 1999. Nesting behavior of the lilaccrowned parrot. Wilson Bull. 111: 488-493.

Snyder, N. \& Beissinger, G. 1992, (eds) New World Parrots in Crisis: Solutions from Conservation Biology. Smithsonian Institution Press, Washington, D.C., USA.

Vaughan, C., N. Nemeth \& L. Marineros. 2003a. Ecology and management of natural and artificial Scarlet Macaw (Ara macao) nest cavities in Costa Rica. Ornitol. Neotrop. 14: 381-396.
Vaughan, C., J. Gack, H. Soloranzo, R. Ray, 2003b. The effect of environmental education on school children, their parents, and community members: a study of intergenerational and intercommunity learning. J. Environ. Educ. 34: 12-21.

Vaughan, C. N. Nemeth, J. Cary \& S. Temple. 2005. Conservation strategies for a Scarlet Macaw (Ara macao) population in Costa Rica. Birdlife Int. 15: 119-130.

Wright, T. F, C. A. Toft, E. Enkerlin-Hoeflich, J. GonzalezElizondo, M. Albornoz, A. Rodriguez-Ferraro, F. Rojas-Suarez, V. Sanz, A. Trujillo, S. R. Beissinger, V. Berovides A., Xiomara Galvez A., A. T. Brice, K. Joyner, J. Eberhard, J. Gilardi, S. E. Koenig, S. Stoleson, P. Martuscelli, J. M. Meyers, K. Renton, A. M. Rodgriguez, A. C. Sosa-Asanza, F. J. Vilella, J. W. Wiley. 2001. Nest poaching in Neotropical parrots. Conserv. Bio. 15: 710-720. 
